\title{
Expected response to early-generation selection for yield and tuber appearance traits in potatoes
}

\section{Respostas esperadas de seleção nas primeiras gerações para caracteres de produção e aparência de tubérculos de batata}

\author{
Vicenti Gonçalves Ney ${ }^{1}$; Laerte Reis Terres ${ }^{2 *}$; \\ Giovani Olegário da Silva ${ }^{3}$; Arione da Silva Pereira ${ }^{4}$
}

\begin{abstract}
The aim of this study was to evaluate the performance of potato clonal families, and to estimate genetic variance, heritability and the expected response to selection of tuber yield and appearance traits in early generations. Twelve potato families were obtained from crosses between two groups of randomly-selected genotypes, including Eliza, C1730-7-94, and C1742-8-95 in group 1; and Shepody, Asterix, Caesar, and White Lady in group 2. The crosses were made in factorial design (3 genotypes $\mathrm{x} 4$ genotypes), and each family consisted of 75 genotypes. Experiments were conducted in the fall of 2010 , with a seedling generation under greenhouse conditions, and in the fall of 2011, with a clonal generation under field condition. High heritability estimates suggest that mild to moderate selection can be applied in the seedling generation to eye depth, eyebrow prominence, tuber curvature, flattening and shape uniformity. The C1742-8-95/White Lady stood out as a superior cross, as did all other crosses with White Lady, regarding tuber appearance and yield traits.
\end{abstract}

Key words: Solanum tuberosum L. Seedling generation. Heritability.

\section{Resumo}

O objetivo do trabalho foi avaliar o desempenho de famílias clonais de batata e estimar a variância genética, herdabilidade e a resposta esperada de seleção quanto a caracteres componentes de produção e aparência de tubérculos de batata nas primeiras gerações. Foram avaliadas 12 famílias de batata obtidas de cruzamentos artificiais entre os dois grupos de genótipos escolhidos ao acaso, grupo 1: Eliza, C1730-7-94 e C1742-8-95; e grupo 2: Shepody, Asterix, White Lady e Caesar. Foram avaliados caracteres componentes de aparência de tubérculo e componentes de produção. Os cruzamentos foram realizados na forma de delineamento genético fatorial (3 genótipos x 4 genótipos), sendo cada família constituída de 75 clones. Os experimentos foram conduzidos nas safras de outono de 2010 em casa de vegetação e 2011 a campo. As altas estimativas de herdabilidade obtidas neste estudo sugerem que na geração de plântula pode-se aplicar seleção com intensidade de leve a moderada para profundidade de olho, proeminência de sobrancelha, curvatura de tubérculo, achatamento de tubérculo, aparência e uniformidade de formato de tubérculo. A família originária do cruzamento C1742-8-95/White Lady se destacou em relação às demais. No conjunto de caracteres de aparência e de produção de tubérculos destacaram-se as famílias em que um dos genitores foi a cultivar White Lady.

Palavras-chave: Solanum tuberosum L. Geração de plântula. Herdabilidade.

\footnotetext{
${ }^{1}$ Eng $^{\circ}$ Agr $^{\circ}$, Mestre, Discente, Universidade Federal de Pelotas, UFPEL, Pelotas, RS, Brasil. E-mail: vicentig@gmail.com

${ }^{2}$ Eng $^{\circ}$ Agr $^{\circ}$, Dr., Discente, UFPEL, Pelotas, RS, Brasil. E-mail: laerte_terres@yahoo.com.br

${ }^{3}$ Eng $^{\circ}$ Agr $^{\circ}$, Dr., Pesquisador, Embrapa Hortaliças, CNPH, Brasília, DF, Brasil. E-mail: giovani.olegario@embrapa.br

${ }^{4}$ Eng $^{\circ}$ Agr $^{\circ}$, Dr., Pesquisador, Embrapa Clima Temperado, CPACT, Pelotas, RS, Brasil. E-mail: arione.pereira@embrapa.br

* Author for correspondence
} 


\section{Introduction}

Owing to its composition, gastronomic versatility and low cost to consumers (PEREIRA, 2003), the potato (Solanum tuberosum L.) represents the third most consumed staple worldwide, after rice and wheat (AGRIANUAL, 2014). Increases in potato crop productivity mostly rely on the use of adaptable cultivars, which provide higher yield per unit area, but also reduce the need for chemical inputs that damage the environment.

The potato reproduces asexually, allowing producers to maintain superior genotypes by clonal propagation. During genetic improvement programs thousands of clones are evaluated in their first generations. Clone retention usually varies between $3 \%$ and $30 \%$ in the seedling and first clonal generation, respectively (SILVA; PEREIRA, 2011). The identification and elimination of undesirable genotypes in the initial generations constitutes a crucial step for a successful selection process. This step eliminates plants with unwanted traits from the field tests, reducing inputs, experimental area, and labor, all of which translate into added costs (XIONG et al., 2002).

Selection efficiency during the seedling generation has been put to question (GOPAL; MINOCHA, 1997; MELO et al., 2011), and potato improvement programs often do not include it. However, a few authors have shown the viability of seedling selection (LOVE et al., 1997; SILVA et al., 2008a, 2008b), which must take into account highheritability traits, as well as tuber traits.

Among genetic parameters, heritability represents one of the most important, as it helps in the definition of the ideal selection intensity to be applied on target populations. It constitutes an indicator of geneticallydefined phenotypic superiority that can be passed on to other generations. In a broad sense, heritability includes additivity, dominance and epistasis; in a narrow sense, it includes only additivity, in proportion to total genetic variance (CARVALHO et al., 2001). Understanding the degree of heritability of different traits in early generations provides a crucial tool for the definition and success of genetic improvement strategies.

The aim of this study was to evaluate the performance of potato clonal families, and to estimate genetic variance, heritability and the expected response to selection for tuber yield and appearance traits in early generations.

\section{Materials and Methods}

The experiments were conducted in the fall seasons of 2010 and 2011, at Embrapa Temperate Climate, Pelotas, state of Rio Grande do Sul, Brazil ( $31^{\circ} 52^{\prime} \mathrm{S}, 52^{\circ} 21^{\prime} \mathrm{W}, 50 \mathrm{~m}$ above sea level).

We evaluated 12 potato families obtained from artificial crossings between two randomly chosen genotype groups, including in group 1: Eliza, C17307-94 and C1742-8-95; and in group 2: Shepody, Asterix, White Lady and Caesar. Crossings were performed in factorial design of 3 genotypes $\mathrm{x} 4$ genotypes, and each family comprised 75 clones.

Potato families were evaluated for tuber appearance traits, including skin roughness; eye depth; eyebrow prominence; tuber shape and shape uniformity; tuber pointiness, curvature and flattening; tuber size and size uniformity; and general appearance. Families were also evaluated for yield traits, including number of tubers, total mass, and mean tuber mass.

During the fall of 2010, the seedling generation was grown in a greenhouse: botanical seeds were germinated in seedbeds and the seedlings transplanted to plastic bags containing $2 \mathrm{~L}$ of commercial substrate for the seedling generation. Each family consisted of 75 genotypes, randomly distributed into blocks. Each block included three plots containing a random sample of 25 seedlings from each family. The spacing between plants was $0.10 \mathrm{~m}$. Seedlings were kept in these conditions until harvest, 77 days after seeding, when the tubers from each plant were evaluated. 
During the fall of 2011, the first clonal generation was cultivated. An average-sized tuber of each genotype was planted in the field following the same experimental design of the seedling generation, but with a spacing of $0.35 \mathrm{~m}$ between plants and $0.80 \mathrm{~m}$ between rows. Adequate soil humidity was maintained through irrigation, and each hectare was treated with two tons of commercial fertilizer formulated at 5-30-10. Cultural practices and pest control followed the recommendations of Pereira (2010). Plants were individually harvested 95 days after planting, and tubers were evaluated.

A scale was used to grade each tuber trait from one to nine (SILVA et al., 2013), as follows: skin roughness (1- rough, 9- smooth), eye depth (1- deep, 9- superficial), eyebrow prominence (1prominent, 9- superficial), tuber shape (1- round, 9- elongated), shape uniformity (1- variable, 9uniform), tuber pointiness (1- pointy, 9- not pointy), tuber curvature (1- curved, 9- not curved), tuber flattening (1- flat, 9- not flat), tuber size (1- small, 9- large), size uniformity (1- variable, 9- uniform) and general appearance (1- poor, 9- good). A good general appearance was the combination of smooth skin, superficial eye depth, superficial eyebrow, shape uniformity, no pointiness, no curvature, no flattening, and size uniformity. Evaluated yield traits included number of tubers, total mass $\left(\mathrm{g}\right.$ plant $\left.\mathrm{t}^{-1}\right)$, and mean tuber mass $(\mathrm{g})$.

The Lilliefors test was used to assess the normal distribution of residuals (CAMPOS, 1983) which were not transformed. Subsequently, analyses of variance were conducted for each generation and, jointly, for the seedling and first clonal generations. Means were clustered by the Scott and Knott test, with a 5\% probability of error, using the Genes statistical package (CRUZ, 2006).

The following model was used in the analysis of variance (CRUZ, 2001):

$$
\mathrm{Y}_{\mathrm{ij}}=\mu+\mathrm{g}_{\mathrm{i}}+\mathrm{e}_{\mathrm{ij}} \text {, for populations, }
$$

where $Y_{i j}$ is the observation of the $i$-th genotype in the $j$-th cut; $\mu$ is the overall mean; $g_{i}$ is the random effect of the $i$-th genotype confounded with environmental effects; $e_{i j}$ is the experimental error associated with the $\mathrm{Y}_{\mathrm{ij}}$ observation.

The variance and heritability components were estimated as described by Vencovsky and Barriga (1992), with the equation:

$$
h^{2}=\frac{\sigma^{2} \mathrm{~g}}{\sigma^{2} \mathrm{~g}+\sigma^{2} \mathrm{e}+\mathrm{r}},
$$

where $\sigma^{2} \mathrm{~g}$ is the genetic variance, $\sigma^{2} \mathrm{e}$ is the error variance and $r$ is the number of repetitions.

Selection gain was calculated with the equation:

$$
\mathrm{GS}_{\mathrm{i}}=\mathrm{pk} \sigma_{\mathrm{gi}} \mathrm{h}_{\mathrm{i}},
$$

where $\mathrm{p}$ is the parental control, $\mathrm{k}$ is the selection intensity, $\sigma_{\mathrm{gi}}$ is the genetic standard deviation of the trait, and $h_{i}$ is the heritability (CRUZ, 2006), with selection intensity of $30 \%$.

\section{Results and Discussion}

Joint analysis of variance of the two generations did not detect significant interactions between family and generation for the following traits: eye depth (EDP), eyebrow prominence (EBP), shape uniformity (SHU), curvature (CUR), flattening (FLT), general appearance (APP) and size (SIZ) (Table 1). There was significant interaction between family and generation for the following traits: shape (SHA), pointiness (POI), size uniformity (SZU), number of tubers (NTU), tuber mass per plant (MAS) and average mass of tubers (AMA). The data for skin roughness (RGH) did not display normality in the distribution of error and were, therefore, disregarded. Significant differences among families occurred for EDP, EBP, SHU, CUR, FLT, and APP.

The relation between the coefficients of genetic and environmental variability $(\mathrm{CVg} / \mathrm{CVe})$ was greater than one for EDP and EBP, which are values considered ideal for selection (CRUZ; CARNEIRO, 2006). The other traits yielded ratios smaller than one, i.e., the environment had greater impact on the observed variability than genetic background (Table 1). 
Successful selection depends on trait heritability, selection intensity and trait phenotypic standard deviation (SILVA; PEREIRA, 2011). A high heritability was observed for EDP, EBP and CUR traits (Table 2), in agreement with other estimates (PINTO, 1999; LOVE et al., 1997; SILVA et al., 2008b). However, heritability values found here for EDP, SHU and FLT were higher than reported by Silva et al. (2007), whereas values for EBP, CUR and APP were lower, probably because of population and environmental differences. The moderately high value estimated for APP in this study diverges from the relatively low estimates of other authors, which would hamper selection efforts (SILVA; PEREIRA, 2011). Among the traits evaluated, the one with lowest heritability was SIZ (0.36), which finds support in previous reports (SILVA et al., 2007), and may result from the different culture conditions between two generations.

The traits SHA, POI, NTU and MAS yielded higher heritability estimates in the seedling generation than in the first clonal generation, indicating that the environment had less influence on these traits when plants were in the greenhouse (Table 3). These findings corroborate the results obtained by Gopal (2001). Silva et al. (2007) also reported that the seedling generation, grown in the greenhouse, yielded a better expression of APP genetic variability than the first clonal generation, probably because of field effects.

The high heritability estimates for SHA, POI, NTU and MAS in the seedling generation resemble results reported by Silva et al. (2007). SHU heritability values were higher in the first clonal generation than in the seedling generation. This pattern may be attributed to difference in culture conditions. In the seedling generation, plants were grown in $2 \mathrm{~L}$ vases, which restricted tuber development. AMA values were similar in both generations, and slightly higher than found by Love et al. (1997).
Heritability can be used to measure selection advancement or gains. The reduction in noninheritable variability during selection may potentiate these gains. The interactions between genotype and environment pose an obstacle to genetic improvement programs, because environmental effects often mask genotype superiority and make selection a hard task (LOVE et al., 1997). In the present study, trait response to selection paralleled trait heritability and genetic variability. Thus, traits with greater heritability displayed greater advances with selection (Tables 2 and 3).

Selection gains during the seedling generation agree with a previous report by Love et al. (1997) indicating that mild selection intensity should be applied to EDP, EBP, NTU, MAS and AMA, all of which had higher selection gains during the study (Tables 2 and 3). These same authors suggested that no selection should be applied to SZU and SHU during the seedling generation, also corroborating selection gains found in the present study (Tables 2 and 3). The responses to selection in the seedling generation were superior to those observed in the first clonal generation, a pattern that agrees with the higher heritability values found in the former generation.

The cultivar development process aims at achieving high averages and high genetic variability for the traits of interest. In the current work, regarding the average values of EDP, potato families formed three groups. The one with more superficial eyes, desired by the consumer (PEREIRA, 2003), consisted of the crosses Eliza/Caesar, C1730-794/Asterix, C1730-7-94/White Lady, C1730-7-94/ Caesar, C1742-8-95/Asterix and C1742-8-95/White Lady. Regarding the trait EBP, two groups were formed. The superior group, with less prominent eyebrows included the same crosses as the best group for EDP, except for the family C1730-794/Asterix (Table 2). These similar results can be attributed to the association between these two traits (SILVA et al., 2007). 


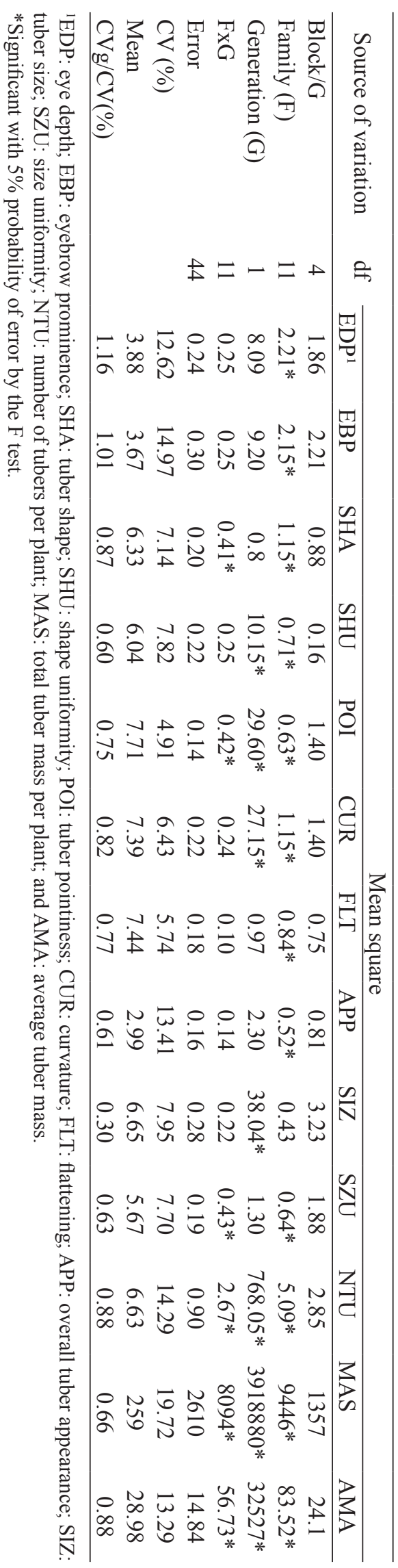

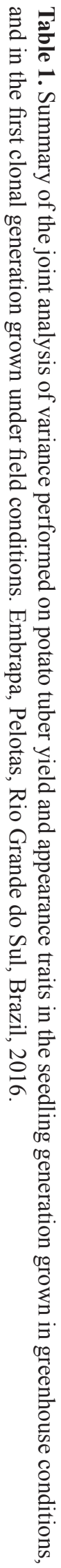


Table 2. Means of two generations and estimates of genetic parameters for tuber yield and appearance traits of potato families evaluated in the seedling generation under greenhouse conditions and first clonal generation under field conditions. Embrapa, Pelotas, Rio Grande do Sul, Brazil, 2016.

\begin{tabular}{lcccccccccccccc}
\hline \multicolumn{1}{c}{ Family\& Parameter $^{2}$} & EDP $^{1}$ & \multicolumn{1}{c}{ EBP } & \multicolumn{1}{c}{ SHU } & \multicolumn{1}{c}{ CUR } & FLT & APP & \multicolumn{2}{c}{ SIZ } \\
\hline Eliza/Shepody & 3.70 & $\mathrm{~b}$ & 3.49 & $\mathrm{~b}$ & 5.97 & $\mathrm{a}$ & 7.24 & $\mathrm{~b}$ & 7.10 & $\mathrm{~b}$ & 2.79 & $\mathrm{a}$ & 6.88 & $\mathrm{a}$ \\
Eliza/Asterix & 3.36 & $\mathrm{~b}$ & 3.18 & $\mathrm{~b}$ & 5.43 & $\mathrm{a}$ & 6.92 & $\mathrm{~b}$ & 7.29 & $\mathrm{~b}$ & 2.71 & $\mathrm{a}$ & 7.08 & $\mathrm{a}$ \\
Eliza/White Lady & 3.41 & $\mathrm{~b}$ & 3.23 & $\mathrm{~b}$ & 6.57 & $\mathrm{a}$ & 8.04 & $\mathrm{a}$ & 7.54 & $\mathrm{a}$ & 3.38 & $\mathrm{a}$ & 6.75 & $\mathrm{a}$ \\
Eliza/Caesar & 4.56 & $\mathrm{a}$ & 4.22 & $\mathrm{a}$ & 5.47 & $\mathrm{a}$ & 6.78 & $\mathrm{~b}$ & 6.80 & $\mathrm{~b}$ & 2.47 & $\mathrm{a}$ & 6.60 & $\mathrm{a}$ \\
C1730-7-94/Shepody & 2.57 & $\mathrm{c}$ & 2.49 & $\mathrm{~b}$ & 6.37 & $\mathrm{a}$ & 8.03 & $\mathrm{a}$ & 7.69 & $\mathrm{a}$ & 2.80 & $\mathrm{a}$ & 6.88 & $\mathrm{a}$ \\
C1730-7-94/Asterix & 3.98 & $\mathrm{a}$ & 3.70 & $\mathrm{~b}$ & 5.93 & $\mathrm{a}$ & 7.07 & $\mathrm{~b}$ & 7.83 & $\mathrm{a}$ & 2.86 & $\mathrm{a}$ & 6.58 & $\mathrm{a}$ \\
C1730-7-94/W. Lady & 4.24 & $\mathrm{a}$ & 4.17 & $\mathrm{a}$ & 6.34 & $\mathrm{a}$ & 7.96 & $\mathrm{a}$ & 7.92 & $\mathrm{a}$ & 3.32 & $\mathrm{a}$ & 6.44 & $\mathrm{a}$ \\
C1730-7-94/Caesar & 4.82 & $\mathrm{a}$ & 4.67 & $\mathrm{a}$ & 5.96 & $\mathrm{a}$ & 7.40 & $\mathrm{~b}$ & 7.20 & $\mathrm{~b}$ & 2.88 & $\mathrm{a}$ & 6.28 & $\mathrm{a}$ \\
C1742-8-95/Shepody & 3.75 & $\mathrm{~b}$ & 3.40 & $\mathrm{~b}$ & 5.96 & $\mathrm{a}$ & 6.96 & $\mathrm{~b}$ & 6.96 & $\mathrm{~b}$ & 2.97 & $\mathrm{a}$ & 6.97 & $\mathrm{a}$ \\
C1742-8-95/Asterix & 4.12 & $\mathrm{a}$ & 4.03 & $\mathrm{a}$ & 6.27 & $\mathrm{a}$ & 7.31 & $\mathrm{~b}$ & 7.48 & $\mathrm{a}$ & 3.16 & $\mathrm{a}$ & 6.38 & $\mathrm{a}$ \\
C1742-8-95/W. Lady & 4.38 & $\mathrm{a}$ & 4.15 & $\mathrm{a}$ & 6.25 & $\mathrm{a}$ & 7.34 & $\mathrm{~b}$ & 7.62 & $\mathrm{a}$ & 3.41 & $\mathrm{a}$ & 6.55 & $\mathrm{a}$ \\
C1742-8-95/Caesar & 3.75 & $\mathrm{~b}$ & 3.34 & $\mathrm{~b}$ & 6.08 & $\mathrm{a}$ & 7.65 & $\mathrm{a}$ & 7.91 & $\mathrm{a}$ & 3.19 & $\mathrm{a}$ & 6.31 & $\mathrm{a}$ \\
\hline $\mathrm{h}^{2}$ & 89.13 & 85.94 & 68.76 & 80.41 & 78.24 & 69.27 & 35.84 \\
CVg (\%) & 14.64 & 15.12 & 4.69 & & 5.27 & 4.42 & 8.18 & 2.38 \\
Mean & 3.88 & 3.67 & 6.04 & 7.39 & 7.44 & & 2.99 & 6.65 \\
Gs (\%) & 14.05 & 14.73 & 3.85 & & 5.73 & 4.13 & & 7.65 & & 1.60 \\
\hline
\end{tabular}

'EDP: eye depth; EBP: eyebrow prominence; SHU: shape uniformity; CUR: curvature; FLT: flattening; APP: overall tuber appearance; SIZ: tuber size.

${ }^{2} \mathrm{~h}^{2}$ : heritability; CVg: coefficient of genetic variation; Gs: Expected gain by selection.

${ }^{3}$ Means followed by the same letter in the column do not differ significantly according to the Scott and Knott test at $5 \%$ probability of error.

Families were also divided into two groups with regards to CUR. The best group, with less curved tubers, included the families Eliza/White Lady, C1730-7-94/Shepody, C1730-7-94/White Lady and C1742-8-95/Caesar. Two groups were formed depending on the degree of FLT. The superior group included the families with better CUR but also the crosses C1730-7-94/Asterix, C1742-8-95/Asterix, C1742-8-95/White Lady and C1742-8-95/Caesar (Table 2).

The overall tuber appearance directly affects consumer preference (SILVA et al., 2008b). In the present study, APP and SHU varied significantly between generations, but no clusters were formed with the Scott and Knott algorithm (5\%). Regarding SHA, crosses between C1730-7-94 and Asterix or Caesar resulted in more elongated tubers in the seedling generation, whereas the other families behaved similarly in the two generations (Table 3 ). In the seedling generation, three SHA groups were formed, where the one with highest averages, i.e., more elongated tubers included the crosses Eliza/Shepody, Eliza/Asterix, C1730-7-94/Asterix, C1730-7-94/Caesar, C1742-8-95/Shepody, C17428-95/White Lady and C1742-8-95/Caesar. The intermediate group, with oval tubers included the crosses Eliza/Caesar, C1730-7-94/White Lady and C1742-8-95/Asterix. The cross between Eliza and White Lady had the lowest average, and its tubers were the closest to round. In the first clonal generation, the crosses Eliza/White Lady, C1730-794/Shepody and C1730-7-94/White Lady formed the group with round tubers, whereas the other families had more elongated potatoes (Table 3). 


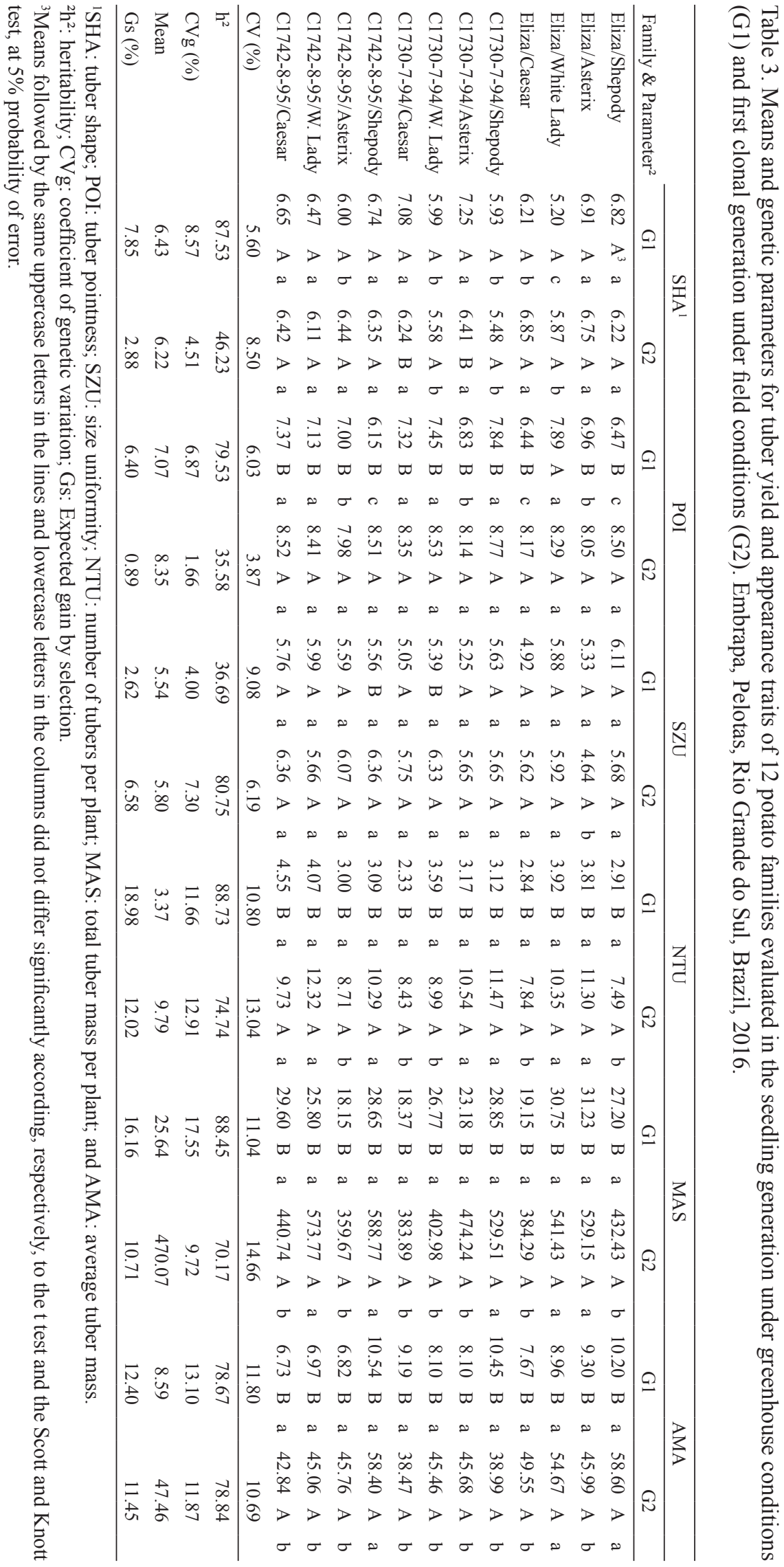


Only the cross between Eliza and White Lady did not differ in POI between generations. In the other families, tubers were pointier, i.e., had lower POI, in the seedling generation. Clustering was only possible in the seedling generation, where the superior group was formed by the cross Eliza/ White Lady, crosses between the clone C1730-794 with cultivars Shepody, White Lady or Caesar, and crosses between the clone C1742-8-95 with White Lady or Caesar. The intermediate group was composed by families that had Asterix as the genitor. The group with worst performance regarding POI included families generated from crosses between Eliza and the cultivars Shepody or Caesar, and from the cross C1742-8-95/Shepody. The only families that differed between generations for SZU originated from the crosses C1730-7-94/ White Lady and C1742-8-95/Shepody, which had more uniformly-sized tubers in the first clonal generation. Clustering was only possible in the first clonal generation, where the cross Eliza/Asterix had the lowest average, while the other families had higher averages translating into greater size uniformity (Table 3).

All families had superior yield traits in the first clonal generation, which was expected, given the limited amount of substrate available for the seedlings. The lower number of tubers, of smaller size, has been indicated as the main obstacle for the application of selection during seedling generation (BROWN et al., 1984; PINTO, 1999; GOPAL; MINOCHA, 1997). Recent studies have focused on the size of the containers where the seedling is grown, and for some traits, the containers should be larger than the usual $250 \mathrm{ml}$ vases used in many potato improvement programs (VERÍSSIMO et al., 2012). In the seedling generation, families could not be clustered using the traits NTU, MAS and AMA. However, in the first clonal generation, the families formed distinct groups, highlighting the crosses Eliza/White Lady and C1742-8-95/Shepody for most traits. The crosses Eliza/Asterix, C1730-7-94/
Shepody and C1742-8-95/White Lady were superior for NTU and MAS; the cross Eliza/Shepody for AMA; and crosses C1730-7-94/Asterix and C17428-95/Caesar with regards to NTU (Table 3).

Joint data analysis indicated that families formed by the White Lady cultivar were superior for most of the traits evaluated (Table 3 ).

\section{Conclusion}

The high-heritability estimates obtained in the present study suggest that mild to moderate selection can be applied to eye depth, eyebrow prominence, curvature, flattening, shape uniformity and overall appearance.

The cross between C1742-8-95 and White Lady was superior in comparison to the others with regards to the combination of overall appearance and number of tubers. In fact, families generated from White Lady were superior for most traits evaluated.

\section{Acknowledgments}

We thank the support team at the Potato Genetic Improvement Program at Embrapa; we also thank CAPES and CNPq for financial support.

\section{References}

AGRIANUAL. Anuário da Agricultura Brasileira. São Paulo, 2014. p. 189-296.

BROWN, J.; CALIGARI, P. D. S.; MACKAY, G. R.; SWAN, G. E. L. The efficiency of seedling selection by visual preference in a potato breeding programme. Journal of Agricultural Science, Cambridge, v. 103, n. 2, p. 339-346, 1984.

CAMPOS, H. de. Estatística experimental nãoparamétrica. 4. ed. Piracicaba: FEALQ, 1983. 349 p.

CARVALHO, F. I. F.; SILVA, S. A.; KUREK, A. J.; MARCHIORI, V. S. Estimativas e implicações da herdabilidade como estratégia de seleção. Pelotas: UFPel, Ed. Universitária, 2001. 99 p. 
CRUZ, C. D. Programa Genes: aplicativo computacional em genética e estatística. Viçosa, MG: Editora UFV, 2001. $648 \mathrm{p}$. 2006. $382 \mathrm{p}$.

Programa Genes: biometria. Viçosa, MG: UFV,

CRUZ, C. D.; CARNEIRO, P. C. S. Modelos biométricos aplicados ao melhoramento genético. Viçosa, MG: UFV, 2006. $585 \mathrm{p}$.

GOPAL, J. Genetic parameters and character associations for family selection potato breeding programmes. Journal of Genetics and Breeding, Rome, v. 55, n. 3, p. 201-208, 2001.

GOPAL, J.; MINOCHA, J. L. Effectiveness of selection at microtuber crop level in potato. Plant Breeding, Malden, v. 116, n. 3, p. 293-295, 1997.

LOVE, S. L.; WERNER, B. K.; PAVEK, J. J. Selection for individual traits in the early generations of a potato breeding program dedicated to producing cultivars with tubers having long shape and russet skin. American Potato Journal, Orono, v. 74, n. 3, p. 199-213, 1997.

MELO, D. S.; PINTO, C. A. B. P.; PEIXOUTO, L. S.; NEDER, D. G.; ASSIS, J. C. Early selection of full-sib potato families. Ciência e Agrotecnologia, Lavras, v. 35, n. 6, p. 1101-1109, 2011.

PEREIRA, A. da S. Melhoramento genético. In: PEREIRA, A. da S.; DANIELS, J. (Org.). O cultivo da batata na região sul do Brasil. Brasília: Embrapa Informação Tecnológica, 2003. p. 105-124.

PEREIRA, A. da S. (Org.). Produção de batata no Rio Grande do Sul. Pelotas: Embrapa Clima Temperado, 2010. 95 p. (Sistema de produção, 19).

PINTO, C. A. B. Melhoramento genético de batata. Informe Agropecuário, Belo Horizonte, v. 20, n. 197, p. 120-128, 1999.
SILVA, G. O. da; NEY, V. G.; TERRES, L. R.; PEREIRA, A. da S.; SUINAGA, F. A. Capacidade de combinação de genitores de batata para caracteres de aparência e rendimento de tubérculos. Revista Ceres, Viçosa, MG, v. 60, n. 4, p. 489-497, 2013.

SILVA, G. O.; PEREIRA, A. da S. Seleção em gerações iniciais para caracteres agronômicos em batata. Horticultura Brasileira, Brasília, v. 29, n. 2, p. 449-455, 2011.

SILVA, G. O. da; PEREIRA, A. da S.; SOUZA, V. Q.; CARVALHO, F. I. F.; FRITSCHE NETO, R. Correlações entre caracteres de aparência e rendimento e análise de trilha para aparência de batata. Bragantia, Campinas, v. 66, n. 3, p. 381-388, 2007.

Seleção para caracteres componentes de

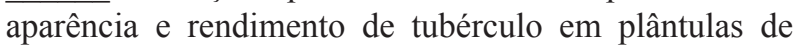
batata. Horticultura Brasileira, Brasília, v. 26, n. 3, p. 325-329, 2008b.

. Seleção para caracteres fenotípicos de tubérculos nas primeiras gerações em batata. Revista Ceres, Viçosa, MG, v. 55, n. 3, p. 168-172, 2008a.

VENCOVSKY, R.; BARRIGA, P. Genética biométrica no fitomelhoramento. Ribeirão Preto: Sociedade Brasileira de Genética, 1992. 486 p.

VERÍSSIMO, M. A. A.; PEREIRA, A. da S.; SILVA, S. D. A.; TERRES, L. R.; NEY, V. G.; SILVA, G. O. Expressão de caracteres de tubérculo em função do tamanho de recipiente usado no cultivo de batata na geração de plântula. Revista Ceres, Viçosa, MG, v. 59, n. 6, p. 787-796, 2012.

XIONG, X.; TAI, G. C. C.; SEABROOK, J. E. A. Effectiveness of selection for quality traits during the early stage in the potato breeding population. Plant Breeding, Malden, v. 121, n. 5, p. 441-444, 2002. 
